\title{
Development of Coordination Test Tools
}

\author{
Sri Gusti Handayani* \\ Sport Education Program \\ Faculty of Sport Science \\ Padang State University \\ Padang, Indonesia \\ srigusti@ fik.unp.ac.id
}

\author{
Anton Komaini \\ Health and Recreation Program \\ Faculty of Sport Science \\ Padang State University \\ Padang, Indonesia
}

\author{
Yohandri \\ Physics Program \\ Faculty of Mathematics and \\ Natural Sciences \\ Padang State University \\ Padang, Indonesia
}

\begin{abstract}
The manual test for measuring hand-eye coordination is throwing catch the ball to the wall at a distance of 2 meters for 15 seconds. In the implementation of the test, there are several obstacles, namely the frequent occurrence of errors in the calculation of the number of throws and catches from the data takers. The purpose of this study was to create a sensor-based hand-eye coordination test instrument. The type of research that is developed is development research, then the stages carried out will be adjusted to the procedures in development research. This research sample is a student at the Faculty of Sport Science. The research results are; 1) creation of hand-eye coordination test based on sensor technology, 2) Results of expert validation stated that the tool was declared "feasible" to be used to measure eye coordination ability.
\end{abstract}

\section{Keywords-coordination, test instruments}

\section{INTRODUCTION}

The Faculty of Sport Science UNP is a institution of higher education that is responsible for fostering a qualified generation and has potential in the physical field. In its implementation, the Faculty of Sport Sciences seeks to compile and organize various types of strategic planning. This strategic planning certainly leads to the tri dharma of higher education, namely teaching, research and community service.

At the beginning of 2015 it was noted that FIK UNP's students numbered 4,327. This person gave a tandem that FIK UNP was a large Faculty and was interested by the community of the Faculty of Sport Sciences as part of the Padang State University. concerning Higher Education, Government Regulation Number 4 of 2014 concerning Organizing Higher Education and Management of Higher Education, Minister of Research, Technology, and Higher Education Number 126 Year 2016 concerning Acceptance of Bana Students Undergraduate Programs at State Universities, is carried out through Selection. National State University Entrance Examination (SNMPTN), Negei State University Entrance Selection (SBMP TN), and 2017 SBMPTN Mandiri Selection are selection based on written test results in paper-based testing or using computer (computer based testing), or a combination Written test results and skills tests for prospective students, carried out jointly under the coordination of the central committee.
Based on experience in carrying out the SBMPTN, namely the selection of new students through a written test or a combination of written test results and skills tests, then in 2017 there will be a written test consisting of Paper Bazed Testing (PBT) and Computer Based Testing (CBT) that can be followed by students graduate 2015, 2016, and 2017 from secondary education (SMA MASMK) and equivalent, as well as graduates of Package C in 2015, 2016, and 2017.

The testulis test that was attended by the PBT and CBT used exam questions designed follow the academic rules of test development SBMPTN written exam is designed to measure basic skills that can predict the siletha of prospective students in all study programs, namely the ability to reason at a higher level (higher orderthinking) which includes academic potential, mastery of basic study fields, science and technology (science) and 'or social and humanities (soshum) fields. Besides taking a written examination (PBT or CBT) participants who choose Art and / or science study programs. Sports are required to take the skills test

Talent, ability and or skills in the field of Arts and Sports cannot be measured only by the results of the Written Examination and or historical record of the report card grades of the 2017 SBMPTN, interests, talents, and potential abilities to attend field education The Arts and Sport Sciences are determined through a combination of the Written Examination and the Skills Examination related to the field of study. The Skills Exams are additional exams for participants who are registering related fields of study. The skills test is an additional test for participants who register in the field of senj and / or sports studies which are carried out after the 2017 SBMPTN written exam.

Based on the description above, it can be seen that one of the tests carried out in the SBMPTN is a skills test, which is for participants who choose the Sport Science study program. The tests carried out include 1) health tests and, 2) motor skills tests. by involving medical personnel (doctors or nurses) as competent parties to provide recommendations for Healthy Healthy conditions for PTNs that do not have adequate medical personnel, can work together with the nearest health agency to carry out a Health Test using health data forms available. Implementation of Health Tests in medical institutions outside PTN is carried out a maximum of 7 (seven) days before the Skills Examination OR Recommends HEALTHY/Unnual Health conditions for 
absolute participants and is a condition for participants to be allowed/not to take the motor skills test.

Motor Skill Test, consisting of Wall Passing, Vertical Jump Upright, Sit-up Test, Push-up Test, Agility Run (llinois Agilit Run test) Cardiorespiratory Endurance (Running 1600m) Based on the description above One of the tests carried out on the SBMPTN above is the Ball Catch to Wall (Wallpass) This test is used to measure the ability to coordinate one's hand's eyes In the implementation of this test has many obstacles namely often the occurrence of calculation of the number of throws and catches of the data taker This is due to the lack of focus in the calculation, so the results obtained are not valid and must be repeated.

Based on this situation, it is necessary to develop an evaluation system on Wall Pass to measure the ability of hand eye coordination that is able to suppress the error element in the implementation of the test. One of them is to develop tools that can assess the assessment system from the conventional to the utilization of technology. One of them is the use of sensors. The sensor used in the development of the Throw Ball to Wall (IWallpass) tool is a force sensor.

Various kinds of sensors today have developed a lot, which with this development sensors become an important component in the electronics field. Not only electronics, sensors also develop in other fields in accordance with the needs and desires of the community. One sensor that is currently developing is the force sensor, and more specifically is flexiforce. The working principle of this sensor is certainly in accordance with its name, which is to detect the force generated by a stimulus that enters a device. The force itself causes a voltage that will cause a certain signal.

The use of force sensors in the development of technology for throwing the ball to the wall (Iallpass) is in accordance with the working principle of the test that gets the numbers.

Another advantage of utilizing this force sensor is that it reduces test time. The results of this study are expected to be able to explain that the use of technology is the right answer in measuring the coordination ability of one's eyes

\section{a) Eye Coordination Hand}

Coordination is the ability to combine a separate nervous system of motion by changing it into an efficient pattern of motion. The more complex a movement is, the higher the level of coordination. According to Harsuki (2003 54) said coordination is the ability to produce new performance as a concoction of various movements as the nervous system and muscles work in harmony

Furthermore, "the physiological point of view the coordination of motion is a manifestation of the regulation of motor processes, especially the work of the muscles that are regulated through the nervous system or called intra muscular coordination" [1]. For this reason, it is necessary to gather energy by coordinating the forces of the motors or other body parts. The development of such a large amount of energy starts from the apparatus of motion or other parts of the body that help to build a large enough amount of energy, then is coordinated and collected and channeled to the muscles.

\section{1) Types of Coordination}

"The types of coordination as follows: 1) Coordination of inter muscles, namely coordination between muscles that work together in doing a garakan The intended cooperation is cooperation between agonist muscles and anthnis in a movement process that directional 2) intra muscle coordination, which is the coordination that occurs in the muscle that cannot be observed, because the process occurs in the muscle" [2].

2) Factors that Affect Coordination

"Coordination can be influenced by 1) Famous athlete's thinking power is not only impressive with amazing skills or good motor skills, but also with ideas and ways to solve complex motor and tactical problems, 2) organ skills and accuracy in the sensory (sensory) motor analysis and kinesthetic sensor and the balance of the rhythm of muscle contraction are important factors in terms of coordination, 3) motor experience, reflected through a variety of high skills is a determining factor in one's coordination ability, or the ability to learn quickly, 4) the level of development of biomotor abilities, such as strength, speed, endurance and flexibility influence the coordination" [3].

3) Coordination Function

"In connection with the coordination function, the existence of coondination a) Can carry out the movement effectively and efficiently Effective in this connection with regard to the efficient use of time, space and energy in carrying out a ger will. While effective is related to the effectiveness of the process that is passed in achieving the goal, b) can utilize physical conditions optimally in breaking down the tasks of the movement, c) the requirements to be able to improve the quality of the implementation of the movement, d) the requirements to be able to master certain sports motor skills" [1].

4) Hand eye coordination

Eye hand coordination is harmony and cooperation between the components of the eye of the hand or other body parts in a precise and controlled sequence when catching the ball to the target wall by measuring how many good numbers for 15 seconds according to the Ballwerfen Undfangen instrument. Eye-hand and foot coordination is a movement that occurs from the information inintegrate into limb movements. All motion must be controllable by sight and must be precise, according to the rules planned in the mind. "Reflecting bouncing the ball, throwing, kicking and stopping it all requires a number of inputs that can be seen, then the input is integrated into motor motion, so that the outcome is really true" [4]. the eye coordination function is "Integration between the eye as the main holder, and the hand as the holder of the function that performs one particular move, in 
this case, both eyes will tell when the ball is at a point so hands immediately swing to do the right punch "[5].

b) Tests and Measurements

Making tests is very important to ensure that they actually measure the factors of bacteria needed to be tested, and thus are objective rather than subjective. Thus all tests must therefore be specific, and have good reliability and objectives. The evaluation process is an integral part of the learning process, which allows teachers to be able to make correct decisions regarding learning achievement Assessment can be done with the aim of setting grades or establishing feedback to diagnose the strengths and weaknesses of the learning process that is taking place (sumati). and see progress in learning (formative). "In the assessment process there are test and measurement activities, the interrelationships between tests, measurements, and evaluations are very close because the assessment process almost always uses tests and measurements to gather information needed at the time of marking" [6].

c) Throw Ball Catch to the Wall

For this instrument is to use the Ball Wer fen and Fengen Test Throw catch the ball to the wall)

a. Preparation

Before data collection, tools are first prepared as follows

1) Walls for throwing targets

2) Gymnastics balls / baseball balls

3) Ribbons / lime to make a circle of throwing targets and throwing distance limits

4) Mattresses

5) Stationery

6) Writing blanks date

b. Implementation of hand eye coordination tests

1) Testee takes the position of throwing behind the throwing line which is $2 \mathrm{M}$ away from the target wall with a gymnastic ball on the throwing hand

2) Testee takes the ball to reflect the ball quickly after the "yes" on cue for 15 seconds

3) Throw is done with the right hand then over the shoulder then catches the reflection of the ball with the left hand and foot not by stepping on the boundary line of the throw or the mat during the catching throw

4) The execution is carried out only once

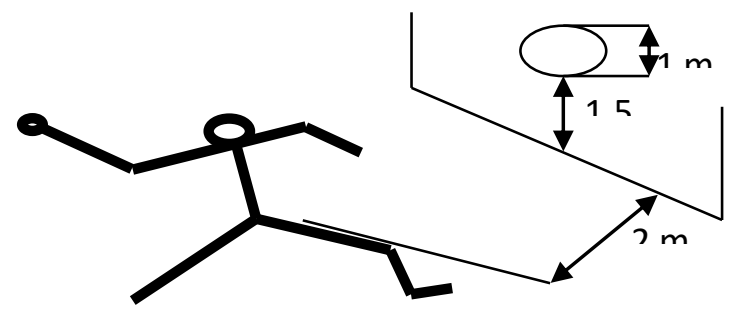

Figure 1. Ball Weifen Und-Fangen Test Source : Haag, H/Dessel (1981) [7]

\section{RESEARCH METHODOLOGY}

Types and Stages of Research

In accordance with the type of research developed namely research development "The following research procedures establishes research and development research procedures consisting of the following steps (1) exploring potential and problems, (2) collecting data, (3) Product design, (4) Design validation (5) Design revision, (6) Product trial, (7) Product revision, (8) Usage trial, (9) Product revision, and (10) Production But the steps of the research and development model are not entirely done by researchers, because of the limited cost and time available" [8].

\section{RESEARCH RESULTS AND DISCUSSION}

Based on the results of the needs analysis and literature study, the initial product is compiled, which is a sensor-based hand eye coordination test instrument equipped with a biomechanic camera.

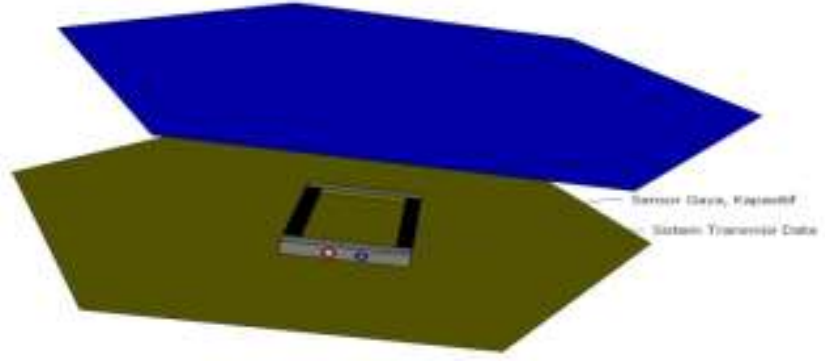

Figure 2. Wall Pass Test Sensor Area
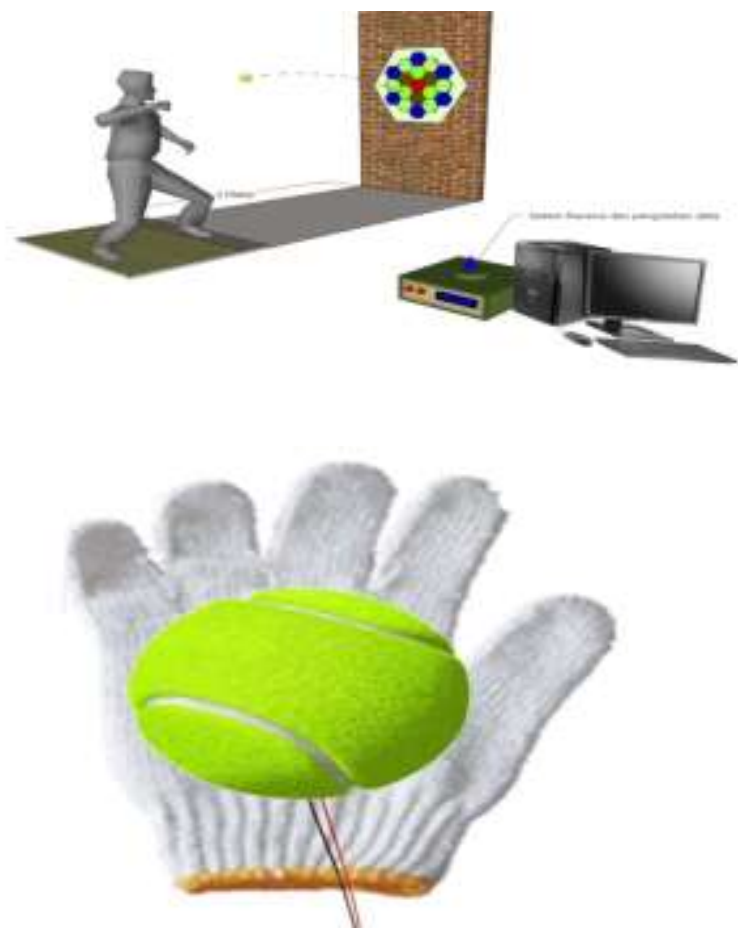

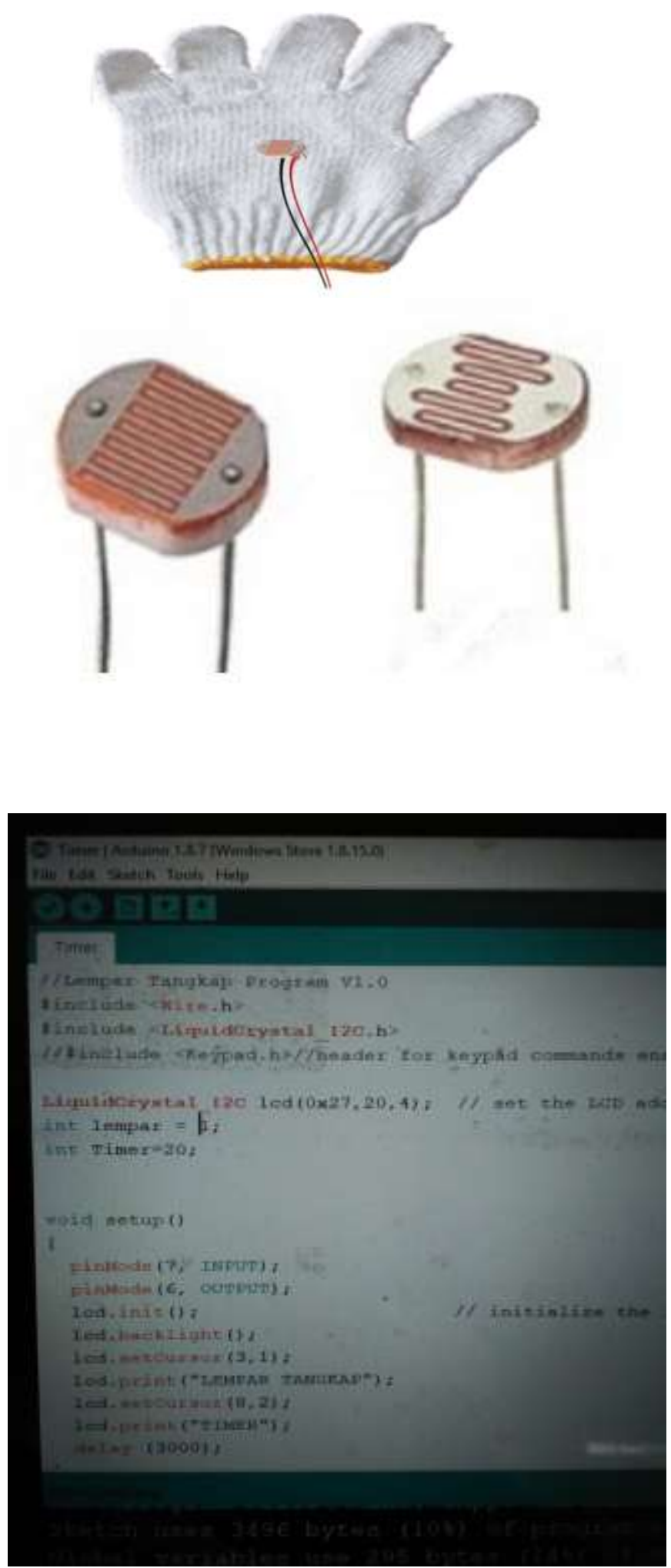

Fig. 3. Wall Pass Test Test tool connected to PC

\begin{tabular}{|c|c|c|}
\hline $\begin{array}{c}\text { Sensor } \\
\text { Conditions }\end{array}$ & $\begin{array}{c}\text { Throw Sensor } \\
\text { Output Voltage }\end{array}$ & $\begin{array}{c}\text { Capture Sensor } \\
\text { Output Voltage }\end{array}$ \\
\hline No Ball & 0 & 0 \\
\hline Ball Obstructed & $4.5 \mathrm{~V}$ & $4.5 \mathrm{~V}$ \\
\hline
\end{tabular}

Subjek stood behind the $2 \mathrm{~m}$ line, after there was a signal "Yes immediately threw to the wall as many times for_15 seconds, the score was calculated based on the number of balls that can be thrown with the right hand then captured by the left hand or vice versa, according to the habits of participants for 30 seconds as many The ball that falls to the floor or to the ground before being caught by the other hand does not count one person is given a chance once and the highest number of tosses and catches recorded will be directly connected to a PC or computer so that the number is more accurate. The sensor used is a force sensor, which stick to the target and gloves of the participant.Flexiforce sensor as a force sensor as mentioned above takes the form of a very thin and flexible printed circuit. The flexiforce sensor is very easy to implement to measure the compressive force between two surfaces in a variety of applications. The conclusions of the product are the core of the product. In the research development of the Agility Test Model Model, there are several conclusions. The following is the conclusions of the research.

\section{CONCLUSION}

Product conclusions are the core of the product in the research model development. There are several conclusions about the agility test tool. The following are the conclusions of the research.

1) The Model of the Hand Eye Coordination Test Tool is made based on digital sensor technology.

2) The Development of the Model The Hand Eye Coordination Test Model is effectively used.

\section{REFERENCES}

[1] Yanuar. "Kemampuan Koordinasi Gerak dan Klasifikasi Aktifitas". Padang: FPOK IKIP Padang. 1994, pp, 52-53.

[2] Syafruddin. "Dasar-dasar Kepelatihan Olahraga". Padang: DIP. 1999, pp. 64-65.

[3] Bompa. "Total Training for Young Champions". York University: Human Kinetics.2000, pp. 31-32.

[4] S. Muhammad. "Pembinaan Kondisi Fisik Dalam Olahraga".Jakarta: P2LPTK, Ditjen Dikti Debdikbud.1985, pp, 1920.

[5] S. Sumosardjono. "Pengetahuan Praktis Kesehatan Dalam Olahraga 2". Jakarta: PT. Gramedia Pustaka Utama. 1990, PP. $42-43$.

[6] Rachman, H.A. "Pengembangan Alat Evaluasi Keterampilan Bermain Softball Berbasis Authentic Assessment”,Majalah Ilmiah Olahraga, vol. 13, no. 3, pp. 275-296, July. 2007.

[7] Haag, Herbet, Hand \& Dassel. "Fitness Test". Stattgart: Karl Verlag Hofman. 7060 Schondorf. 1981, pp. 71-72

[8] Sugiyono. "Metode penelitian kuantitatif kualitatif dan R\&D". Bandung: alfabeta.2014, pp. 69-70 